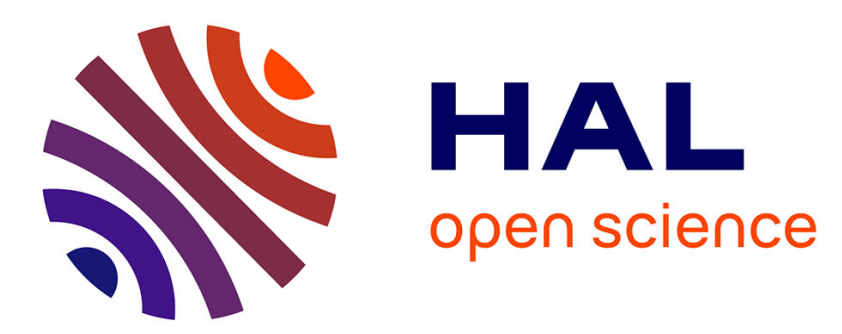

\title{
The Effect of Grain Boundary Impedance on the Power Loss of Mn-Zn Ferrites over $1 \mathrm{MHz}$
}

\author{
M. Tung, T. Tseng, M. Tsay, W. Chang
}

\section{To cite this version:}

M. Tung, T. Tseng, M. Tsay, W. Chang. The Effect of Grain Boundary Impedance on the Power Loss of Mn-Zn Ferrites over 1 MHz. Journal de Physique IV Proceedings, 1997, 07 (C1), pp.C1-129-C1-130. 10.1051/jp4:1997142 . jpa-00255089

\section{HAL Id: jpa-00255089 https://hal.science/jpa-00255089}

Submitted on 1 Jan 1997

HAL is a multi-disciplinary open access archive for the deposit and dissemination of scientific research documents, whether they are published or not. The documents may come from teaching and research institutions in France or abroad, or from public or private research centers.
L'archive ouverte pluridisciplinaire HAL, est destinée au dépôt et à la diffusion de documents scientifiques de niveau recherche, publiés ou non, émanant des établissements d'enseignement et de recherche français ou étrangers, des laboratoires publics ou privés. 


\title{
The Effect of Grain Boundary Impedance on the Power Loss of Mn-Zn Ferrites over $1 \mathrm{MHz}$
}

\author{
M.J. Tung, T.Y. Tseng, M.J. Tsay* and W.C. Chang** \\ Institute of Electronics, National Chiao Tung University Hsinchu, Taiwan, China \\ * Material Research Laboratories, ITRI, Hsinchu, Taiwan 310, China \\ ** Department of Physics, National Chung Cheng University Ming-Hsiung, Chia-Yi 621, Taiwan, China
}

\begin{abstract}
Recently, the operating frequency of switching mode power supplies has been increased from $25 \mathrm{kHz}$ to several $\mathrm{MHz}$ to enhance their efficiency in a smaller size. Although, it was reported that $\mathrm{Mn}-\mathrm{Zn}$ ferrites can also be used at $1 \mathrm{MHz}$, only few papers have discussed the possibility of using $\mathrm{Mn}-\mathrm{Zn}$ ferrites at the frequency higher than $1 \mathrm{MHz}$. Our early paper reported that the core loss of low loss grade $\mathrm{Mn}-\mathrm{Zn}$ ferrites is strongly dependent upon the capacitance of grain boundaries of sintered cores. In frequency region between $1 \mathrm{MHz}$ to $3 \mathrm{MHz}$, the dielectric loss dominates the core loss, while eddy current loss is the major factor of the core loss in $3 \mathrm{MHz}$ to $10 \mathrm{MHz}$. It is suggested that decreasing the grain boundary capacitance at middle high frequency or increasing the grain resistivity at high frequency region are the appropriate ways for $\mathrm{Mn}-\mathrm{Zn}$ ferrites to be used at the frequency between $1 \mathrm{MHz}$ and $10 \mathrm{MHz}$. This paper investigated the core loss of $\mathrm{Mn}-\mathrm{Zn}$ ferrites in the frequency range between $1 \mathrm{MHz}$ and $10 \mathrm{MHz}$ in order to improve the properties of the $\mathrm{Mn}-\mathrm{Zn}$ ferrite cores for their potential applications in this frequency region.

The powders containing $\mathrm{Fe}_{2} \mathrm{O}_{3}, \mathrm{MnO}$ and $\mathrm{ZnO}$ in a molar ratio of 54.2:37.3:8.5 with the addition of $\mathrm{CaO}$ and $\mathrm{SiO}$ from 150 $\mathrm{ppm}$ to $450 \mathrm{ppm}$ were prepared by a conventional ceramic process. Samples were sintered at $1150^{\circ} \mathrm{C}$ to $1250^{\circ} \mathrm{C}$ for $2 \mathrm{hrs}$ then annealed at various condition. The results show that the sintering temperature and annealing condition altered the grain boundary impedance. For example, the grain boundary capacitance changes from $13 \mathrm{pF}$ to $7 \mathrm{pF}$, meanwhile, the dielectric loss factor is lowered from $0.28 \times 10^{-9}$ to $0.17 \times 10^{-9}$, and consequently the power loss decreases from $253 \mathrm{KW} / \mathrm{m}^{3}$ to $145 \mathrm{KW} / \mathrm{m}^{3}$ at $2.5 \mathrm{MHz}$.

Introduction: $\mathrm{Mn}-\mathrm{Zn}$ ferrites are widely used as core material in electronic devices, especially for the switching mode power supply (SMPS). Nowadays the working frequency of SMPS is increased to several $\mathrm{MHz}$ to meet the requirement of higher efficiency and low profile. Our previous study shows that the power loss at the frequency higher than $1 \mathrm{MHz}$ is influenced not only by the hysteresis and eddy current loss but also by the dielectric loss. The dielectric loss is affected by grain boundary capacitance in the range from $1 \mathrm{MHz}$ to $3 \mathrm{MHz}$. In this study, we reduced the dielectric loss by increasing the grain boundary impedance.
\end{abstract}

Experimental: Low loss grade $\mathrm{Mn}-\mathrm{Zn}$ ferrite samples were prepared by a conventional ceramic process. The powders containing $\mathrm{Fe}_{2} \mathrm{O}_{3}, \mathrm{MnO}$ and $\mathrm{ZnO}$ in a molar ratio of 54.2:37.3:8.5 were prepared with the addition of $450 \mathrm{ppm}$ of $\mathrm{CaO}$ and 150 ppm or $250 \mathrm{ppm}$ of $\mathrm{SiO}_{2}$. The powders were pressed into toroids of $20 \mathrm{~mm}$ (O.D.) $\times 10 \mathrm{~mm}$ (I.D.) $\times 5 \mathrm{~mm}(\mathrm{t})$ and disks of 11 $\mathrm{mm}(\varphi) \times 2.5 \mathrm{~mm}(\mathrm{t})$. The green compacts were sintered at $1150^{\circ} \mathrm{C}$ or $1250^{\circ} \mathrm{C}$ for $2 \mathrm{hrs}$ in air and then annealed at $1100^{\circ} \mathrm{C}$ for $2 \mathrm{hrs}$ in a controlled atmosphere of $1 \%$ oxygen partial pressure. The samples were then cooled from $1100^{\circ} \mathrm{C}$ to $800^{\circ} \mathrm{C}$ at different rates $(2 \mathrm{hrs}, 4 \mathrm{hrs} 6 \mathrm{hrs}$ and $8 \mathrm{hrs}$ ) respectively, in order to study the effect of cooling rate on the resistivity and power loss of the sintered cores. The impedance and permeability were measured in the frequency range from $5 \mathrm{~Hz}$ to $13 \mathrm{MHz}$ with HP 4192A impedance analyzer. Power loss was measured with Ryowa MMS-0375 Iron loss measuring system at constant $\mathrm{B}_{\text {meas }} \times \mathrm{f}_{\text {meas }}(=25 \mathrm{kHz} \cdot$ Tesla $)$ value.

Results and Discussion: Table 1 shows the permeability and core loss of the samples sintered at $1150^{\circ} \mathrm{C}(\mathrm{sample} \mathrm{A}, \mathrm{B}, \mathrm{C})$ and $1250^{\circ} \mathrm{C}$ (Sample D, E, F). This table shows that the higher sintering temperatures resulted in good permeability and core loss. Figure 1 shows the variation of core loss with frequency of the samples sintered in various annealing conditions. It is apparent that the core loss of the samples measured at $\mathrm{f} \times \mathrm{B}=25 \mathrm{KHz}$. Tesla can be divided into three regions. The first part is the loss in the frequency lower than $1.2 \mathrm{MHz}$, where the core loss is in proportion to $1 / \mathrm{f}$. The second portion is from $1.2 \mathrm{MHz}$ to around $3 \mathrm{MHz}$, where the core loss is proportional to $\mathrm{f}$. The third region is from $3 \mathrm{MHz}$ to $5 \mathrm{MHz}$, in which the loss is independent of the measured frequencies. 
Table 1. The effect of sintering temperature and annealing time on permeability and core loss

\begin{tabular}{|l|c|c|c|}
\hline Annealing time & $2 \mathrm{hrs}$ & $4 \mathrm{hrs}$ & $6 \mathrm{hrs}$ \\
\hline \hline Sample identification & $\mathrm{A}$ & $\mathrm{B}$ & $\mathrm{C}$ \\
\hline Initial permeability & 1262 & 1204 & 1181 \\
\hline core loss $\left(\mathrm{KW} / \mathrm{m}^{3}\right)^{*}$ & 222.4 & 223.1 & 222.7 \\
\hline Sample identification & $\mathrm{D}$ & $\mathrm{E}$ & $\mathrm{F}$ \\
\hline Initial permeability & 1844 & 1851 & 1822 \\
\hline core loss $\left(\mathrm{KW} / \mathrm{m}^{3}\right)^{*}$ & 184.9. & 189.6 & 172.9 \\
\hline
\end{tabular}

*:at $2.5 \mathrm{MHz} / 10 \mathrm{mT}$

Table 2: Physical properties of the samples $F$ and $G$

\begin{tabular}{|l|c|c|}
\hline Sample identification & $\mathrm{F}$ & $\mathrm{G}$ \\
\hline Annealing time & $6 \mathrm{hrs}$ & $10 \mathrm{hrs}$ \\
\hline $\mathrm{CaO}-\mathrm{SiO}_{2}(\mathrm{ppm})$ & $450 / 150$ & $450 / 250$ \\
\hline grain boundary capacitance $(\mathrm{Cb}: \mathrm{pF})$ & 13 & 6.6 \\
\hline $\mathrm{X}_{\mathrm{Cb}}(\mathrm{ohm} / 2.5 \mathrm{MHz})$ & 4.9 & 9.6 \\
\hline grain boundary resistance $(\mathrm{ohm})$ & 254 & 401 \\
\hline grain boundary impedance & 4.8 & 9.4 \\
\hline Initial permeability & 1822 & 1912 \\
\hline core loss $\left(\mathrm{KW} / \mathrm{m}^{3}\right)(2.5 \mathrm{MHz} / 10 \mathrm{mT})$ & 172.9 & 145.1 \\
\hline
\end{tabular}

The core loss of power ferrite is reported consisting of three factors, namely, hysteresis $\operatorname{loss}\left(\mathrm{P}_{\mathrm{h}}\right)^{1,2}$, eddy current loss $\left(\mathrm{P}_{\mathrm{e}}\right)^{1,2}$ and dielectric loss $\left(P_{d e}\right)^{3}$. These factors are all heavily dependent upon the frequency and flux density. If the measuring condition is kept at a constant $\mathrm{f} \times \mathrm{B}$, the three factors of the core loss can be defined as follows:

$$
\begin{aligned}
& \mathrm{P}_{\mathrm{h}}=\mathrm{K}_{\mathrm{h}}(\mathrm{f} \times \mathrm{B})^{2} / \mathrm{f} \\
& \mathrm{P}_{\mathrm{e}}=\mathrm{K}_{\mathrm{e}}(\mathrm{f} \times \mathrm{B})^{2} / \rho \\
& \mathrm{P}_{d e}=\mathrm{K}_{d e}(\mathrm{f} \times \mathrm{B})^{2} \times \mathrm{f}
\end{aligned}
$$

where $\mathrm{K}_{\mathrm{h}}, \mathrm{K}_{\mathrm{e}}$ and $\mathrm{K}_{\mathrm{de}}$ represent the coefficient of hysteresis loss, eddy current loss and dielectric loss, respectively. $B$ represents the magnetic induction, $f$ represents the frequency and $\rho$ represents the resistivity of the core.

From equation (1) to (3), it clearly shows that $P_{h}$ is proportional to $1 / f, P_{e}$ has no relationship with $f$, while $P_{d e}$ is proportional to $\mathrm{f}$, if $\mathrm{f} \times \mathrm{B}$ is kept constant. That means the core loss of the studied samples is dominated by dielectric loss in the frequency from $1 \mathrm{MHz}$ to $3 \mathrm{MHz}$. Follows the Kroops' model $^{4}$, the impedance of the sample will be dominated by the grain boundary resistivity $(\mathrm{Rb})$ at low frequency, while it will be dominated by the grain resistivity $(\mathrm{Rg})$ at high frequency due to rapid decrease of $\mathrm{Xcb}(=1 / \omega \mathrm{Cb})$. It is presumed that the increase of grain boundary impedance may cause the decrease of eddy current loss, i.e., the core loss. Therefore, at the frequency between $1 \mathrm{MHz}$ and $3 \mathrm{MHz}$, it is suggested that the decrease of the grain boundary capacitance $(\mathrm{Cb})$ would cause the decrease of its core loss, i.e., the dielectric loss.

In order to prove the grain boundary capacitance on the core loss in the frequency from $1 \mathrm{MHz}$ to $3 \mathrm{MHz}$, the samples with higher $\mathrm{CaO}-\mathrm{SiO}_{2}$ additive and longer cooling condition was applied in order to alter the thickness of the grain boundary phase, or the capacitance of the grain boundary. Table 2 lists the properties of the studied samples in this experiment.

It is apparent that $\mathrm{Cb}$ of the sample $\mathrm{G}$ is smaller than that of the sample $\mathrm{F}$, and the grain boundary impedance are dominated by impedance of $\mathrm{Cb}$. It is found that the core loss of sample $\mathrm{G}$ is lower than that of the sample $\mathrm{F}$ at the frequency of $2.5 \mathrm{MHz}$. This result reveals the importance of grain boundary capacitance at the middle high frequency, i.e., $1 \sim 3 \mathrm{MHz}$ in this study.

Conclusions: The core loss of low loss grade $\mathrm{Mn}-\mathrm{Zn}$ ferrites is strongly dependent upon the frequency under the condition of $\mathrm{f} \times \mathrm{B}=25 \mathrm{KHz} \cdot \mathrm{T}$. At the middle high frequency region (1.2 MHz $\sim 3 \mathrm{MHz}$ ), the dielectric loss dominates the core loss. It is suggested that by decreasing the grain boundary capacitance at middle high frequency is the appropriate way to improve the properties of the $\mathrm{Mn}-\mathrm{Zn}$ ferrites and permits its application in this frequency range .

Acknowledgment: The authors would like to express their deep gratitude to the Ministry of Economic Affairs of Taiwan, Republic of China, for supporting this study under contract No.85-3KF2200.

\section{References:}

[1] E.C. Snelling and A.D. Giles, "Ferrite for Inductors and Transformers", Philips Research Laboratories, Redhill, Surry, England. p.54-62,1983.

[2] J. Smit and H.P.J. Wijn, "Ferrites", Philips Technical Library, Eindhoven, p. 134, 1959.

[3] S.Yamada, E.Otsuki and T.Otsuka,Ac Resistivity of Mn-Zn Ferrites",Tokin Technical Review, Vol.18, p.16-23, 1991.

[4] C.G.Koops. "On the Dispersion of resistivity and Dielectric Constant of Some Semiconductors at Audio frequencies",Phys. Rev., Vol. 83-1, p.121-124, 1951. 